\title{
Plant growth promoting capability and genetic diversity of bacteria isolated from mud volcano and lime cave of Andaman and Nicobar Islands
}

\author{
Gopu Venkadesaperumal, Natrajan Amaresan, Krishna Kumar
}

Division of Field Crops, Central Agricultural Research Institute, Andaman and Nicobar Islands, India.

Submitted: September 26, 2013; Approved: April 17, 2014.

\begin{abstract}
Twenty four bacterial strains from four different regions of mud volcano and lime cave were isolated to estimate their diversity, plant growth promoting and biocontrol activities to use them as inoculant strains in the fields. An excellent antagonistic effect against four plant pathogens and plant growth promoting properties such as IAA production, HCN production, phosphate solubilization, siderophore production, starch hydrolysis and hydrolytic enzymes syntheses were identified in OM5 (Pantoea agglomerans) and EM9 (Exiguobacterium sp.) of 24 studied isolates. Seeds (Chili and tomato) inoculation with plant growth promoting strains resulted in increased percentage of seedling emergence, root length and plant weight. Results indicated that co-inoculation gave a more pronounced effects on seedling emergence, secondary root numbers, primary root length and stem length, while inoculation by alone isolate showed a lower effect. Our results suggest that the mixed inocula of OM5 and EM9 strains as biofertilizers could significantly increase the production of food crops in Andaman archipelago by means of sustainable and organic agricultural system.
\end{abstract}

Key words: plant growth promotion, phytopathogens, mud volcano, lime cave, amplified ribosomal DNA restriction analysis (ADRDA).

\section{Introduction}

Sustainable agriculture has evolved from three perspectives: system of production to achieve self-sufficiency in food, concept of stewardship and means of sustaining rural communities. The indiscriminate use of chemical pesticides not only causes pollution but also leads to uncalled losses of microbial diversity in the natural environment. In view of this, usage of bio based fertilizers and pesticides are one of the promising ways to enhance crop productivity and to manage the plant diseases. In this view, use of plant growth promoting bacteria has an important role in developing promising method for crop management (Sturz et al., 2000). The PGPR mechanisms to promote plant growth are of diverse nature such as phosphorus solubilization, production of plant hormones (Bent et al., 2001; Reyes et al., 2002) and excretion of diverse compounds like antibiotics or proteolytic enzymes. Some plant-beneficial microorganisms are known to antagonize plant pathogens through competition for nutrients; parasitism by means of hydro- lytic enzyme production; inhibition of the pathogens by anti-microbial compounds; induction of systemic resistance in host plants (Whipps, 2001; Compant et al., 2005).

Mud volcanoes are featured where mixed fluid-rich fine-grained sediments, associated with fragments of rocks or consolidated mud, are expelled at the earth's surface or on the seafloor (Staffini et al., 1993). It was discovered that the immediate surroundings of these volcanoes are constituted of micro-organisms, of which $99 \%$ are still unidentified today. One of 1,100 mud volcanoes is located in the Island of Baratang, part of the Great Andaman archipelago, where there was a significant eruption event in 2003.

In Andaman and Nicobar Islands, out of total geographical area of 8,249 sq. $\mathrm{km}$ land, only $9 \%$ land is used for vegetable cultivation. The wilt caused by bacterial pathogen Ralstonia solanacereaum, fungal pathogen Fusarium sp., damping off caused by Pythium sp., root rot by Rhizoctonia sp. and Macrophomina sp., collar rot caused by Sclerotium rolfsii and anthracnose caused by Colletotrichum sp., were reported to cause severe damage 
to the vegetable crops in Andaman and Nicobar Islands. As a new inch in the search of agriculturally important microorganisms from various sources, here the microorganisms have isolated from Mud Volcano, one of the natural gift of the great Andaman archipelago. Though studies proving that the microorganisms isolated from the terrestrial mud volcano shows potentiality like hydrocarbon utilization and production of methane gas (Alain, 2006) the current study was carried out to find out their potential microbial source as plant growth promoters and effective biocontrol agent.

\section{Materials and Methods}

\section{Sampling regime and physic-chemical analysis}

Volcano samples were collected from the Island of Baratang, part of the great Andaman archipelago, Indian Ocean. The samples has been collected from the different points of mud volcano (12 $07^{\prime} 46.5^{\prime \prime}$ latitude; $092^{\circ} 47^{\prime} 31.2^{\prime \prime}$ longitude) viz., point of the eruption (PM), end of the volcano (EM), dried part of the mud volcano (DM), outside of the mud volcano (OM) and the soil sample from Lime Cave (LC) $\left(12^{\circ} 05^{\prime} 37.6^{\prime \prime}\right.$ latitude; 092 44'38.5") were collected to obtain a representative composite sample. In subsamples $\mathrm{pH}$, electrical conductivity, available nitrogen, potassium and phosphorous contents as described by Jacob Parnell (1996) and the results were shown in Table 1. For isolation of bacteria, $1 \mathrm{~g}$ of each soil sample was suspended into $9 \mathrm{~mL}$ of sterile saline solution. Ten-fold of serial dilution was performed then $0.1 \mathrm{~mL}$ of aliquot was used for pour plating on nutrient agar plates (Anon, 1957). The plates were maintained at $28 \pm 2{ }^{\circ} \mathrm{C}$ for 48 to $72 \mathrm{~h}$, total colonies were enumerated and the colonies showing visible morphological differences were isolated. Counts were done after $24 \mathrm{~h}$ of incubation at $25^{\circ} \mathrm{C}$ and results were expressed as colony forming units (cfu) $\mathrm{g}^{-1}$ soil (on a dry-weight basis). A total of 52 bacterial isolates were isolated from five soil samples of mud volcano and lime cave soils were purified and maintained on $20 \%$ glycerol stock and nutrient agar slant for the further experiments and analysis.

\section{Morphological and biochemical characterization}

Each isolate was subjected to morphology, motility and 3\% KOH solubilization test (Suslow et al., 1982). Biochemical tests were also performed. Nitrate reduction ability of the organisms was determined as described by García de Salamone et al. (1996). Oxidase activity was measured using the reactive discs from Himedia, India. Based on morphological and biochemical characterization 24 of 52 isolates were selected for PGPR and diversity analysis.

\section{Plant growth promoting properties}

Indole acetic acid production

Inocula were transferred to tryptone broth was used to quantify auxin production. Sterilized tryptone broth was inoculated with the test culture and incubated at $30{ }^{\circ} \mathrm{C}$ for 48 and $72 \mathrm{~h}$ with occasional shaking. The tubes were centrifuged at 15,500 $\mathrm{g}$ for $2 \mathrm{~min}$ and auxin production was measured as indole-3-acetic acid (IAA) equivalents, as follows: Equal volume of culture supernatant was added with Salkowski reagent $\left(12 \mathrm{~g} \mathrm{~L}^{-1} \mathrm{FeCl}_{3}+7.9 \mathrm{MH}_{2} \mathrm{SO}_{4}\right)$. The mixture was allowed to stand for $30 \mathrm{~min}$ for color development. Color intensity was measured spectrophotometrically at $550 \mathrm{~nm}$ using a standard curve (Sarwar and Kremer, 1992).

\section{Mineral phosphate solubilization}

Phosphate solubilization ability of isolates was assessed qualitatively using Pikovaskaya's agar medium (Pikovaskaya, 1948) containing tricalcium phosphate (5 g/L). Each bacterial culture was spot inoculated in the centre of a plate and incubated at $28 \pm 2{ }^{\circ} \mathrm{C}$ for $48 \mathrm{~h}$. Clear/halo zone indicates the positive cultures. The halo zone was calculated by subtracting bacterial colony diameter from the total halo zone diameter (Freitas et al., 1997). Each test was replicated three times

\section{Siderophore production assay}

Qualitative assay was done based on strains competition for iron on medium supplemented with ferric complex of chrome azurol S (CAS) as described by Schwyn and Neilands (1987). The nutrient agar medium was supplemented with CAS $60.5 \mathrm{~g}$ in $50 \mathrm{~mL}$, Iron III solution $(1 \mathrm{mM}$ $\mathrm{Fecl}_{3} \cdot \mathrm{H}_{2} \mathrm{O}$ and $10 \mathrm{mM} \mathrm{Hcl}$ in $10 \mathrm{~mL}$ ) and HDTMA (72.9 mg in $40 \mathrm{~mL}$ ). The isolates were spot inoculated on the plates and incubated for $48 \mathrm{~h}$ at $30{ }^{\circ} \mathrm{C}$. Development of yellow-orange halo zone around the culture was considered as positive for siderophore production.

\section{Screening for cyanide production}

HCN production by the isolates was examined as described by Bakker and Schipper (1957). The isolates were

Table 1 - Abiotic characteristics of the soils.

\begin{tabular}{|c|c|c|c|c|c|}
\hline Sample & $\mathrm{pH}$ & $\mathrm{EC}$ & Available nitrogen $(\mathrm{kg} / \mathrm{ha})$ & Available phosphorous (kg/ha) & Available potassium $(\mathrm{kg} / \mathrm{ha})$ \\
\hline DM & 7.5 & 2.3 & 8.4 & 21 & 95 \\
\hline EM & 8.6 & 5.6 & 5.6 & 16 & 150 \\
\hline $\mathrm{LC}$ & 8.5 & 0.4 & 25.2 & 40 & 145 \\
\hline OM & 7.4 & 0.2 & 14.0 & 15 & 145 \\
\hline PM & 8.9 & 4.9 & 5.6 & 20 & 155 \\
\hline
\end{tabular}


streaked on plates containing King's B medium amended with glycine $(4.4 \mathrm{~g} / \mathrm{L})$ and the lid of each Petri plate placed Whatman no. 1 filter paper soaked in $0.5 \%$ picric acid in $2 \%$ sodium carbonate. The plates were then sealed with parafilm and incubated at $28 \pm 2{ }^{\circ} \mathrm{C}$ for 4 days. Change of color from yellow to orange and then to dark brown in the filter paper indicated as positive reaction and the absence as negative reaction.

\section{Antagonistic activity}

The phytopathogenic fungi Rhizoctonia solani (ITCC 6376), Pythium aphanidermatum (ITCC 5488) and Macrophomina sp. (ITCC 5519) were collected from the Indian Type Culture Collections Centre, IARI, New Delhi and Sclerotium (Athelia) rolfsii (MTCC 288) collected from Microbial Type Culture Collection, IMTECH, Chandigarh.

The antagonistic ability of bacterial isolates was determined by dual culture technique as described by Dennis and Webster (1971). Six millimeter agar discs containing grown mycelia of any of the four phytopathogenic fungi were at approximate distance apart on a PDA dish. Four bacterial isolates were streaked between the agar discs. Inhibition of fungal mycelium around the bacterial colony was scored for 2-3 days by measuring the radial growth of the pathogen. PDA plate inoculated only with pathogen was taken as control. All strains were tested in two replicates on different plates and the tests were carried out twice for each isolate.

Percentage of inhibition was calculated by the following formula

$$
I=\frac{C-T}{C} * 100,
$$

where, $I$ is percent inhibition of growth, $C$ is mycelial growth in control plate, $T$ is mycelial growth in test plate.

\section{Production of hydrolytic enzymes}

\section{Screening for cellulase production}

The fresh culture was spot inoculated on the pre poured Sodium carboxy methyl cellulose (CMC) medium. The plate was incubated for $2-3$ days at $28 \pm 2{ }^{\circ} \mathrm{C}$. Plates were then flooded with Gram's iodine to visualize halo zone around the bacterial colony, which indicates positive result in utilizing of the cellulose substrate.

\section{Screening for protease production}

Proteolytic activities of the cultures were screened qualitatively in a medium containing skim milk. Fresh culture was streaked onto the medium and incubated at room temperature for 24-48 h. Clear zone formation around the colony indicates the proteolytic activity of the bacterium as positive and absence as negative.

\section{Intrinsic antibiotic resistance (IAR) test}

Bacterial isolates were screened for their sensitivity or resistance to antibiotics. IAR has also been used in the genotypic identification of bacterial species. Plate of Muller Hinton Agar was swabbed with fresh culture; fourteen different antibiotic discs were pressed gently on the surface of the plate at sufficient distance and incubated at $28 \pm 2{ }^{\circ} \mathrm{C}$ for 3 days. The presence of inhibition zones around the discs of the different antibiotics were noted (Bauer et al., 1966). Each test was replicated three times.

\section{Salt tolerance}

A plates containing beef extract, peptone plus sodium chloride at different concentration (7-12\%) was inoculated with $20 \mu \mathrm{L}$ aliquot of an overnight test culture. The plates were then incubated at room temperature for 24-48 h. Growth on the culture media plates is recorded as positive and absence of growth is recorded as a negative.

\section{Genotypic characterization of bacterial isolates}

The selected bacterial strains exhibiting pronounced in vitro PGP qualities were characterized for their diversity analysis. Genomic DNA was extracted based on the method described by Chen and Kuo (1993). DNA was electrophoresed on 1\% agarose, ethidium bromide gel.

One hundred nanograms of DNA were used as template in PCR procedures. Selected primers $\mathrm{pA}$ and $\mathrm{pH}$ (5'-AGAGTTTGATCCTGGCTCAG-3' and 5'-AAGGAGGTGATCCAGCCGCA-3' respectively) were used for amplification as described by Edwards et al. (1989). The mixture was subjected to initial denaturation of $92^{\circ} \mathrm{C}$ for $2 \mathrm{~min}$ and $10 \mathrm{~s}$ followed by 35 cycles of $92^{\circ} \mathrm{C}$ for $1 \mathrm{~min}, 48^{\circ} \mathrm{C}$ for $30 \mathrm{~s}$ and $72^{\circ} \mathrm{C}$ for $2 \mathrm{~min}$ and $10 \mathrm{~s}$ and a final extension step of $72{ }^{\circ} \mathrm{C}$ for $6 \mathrm{~min}$ and $10 \mathrm{~s}$ using GeneAmp ${ }^{\circledR}$ PCR system 9700 (Applied Biosystems, USA). The PCR products were resolved using a $1.5 \%$ agarose gel photographed under UV transillumination. PCR products of $1.5 \mathrm{~kb}$ were sent to commercial gene se-

Table 2 - Summary of the 16S rDNA sequences from some bacterial strains with plant growth promoting properties.

\begin{tabular}{lcc}
\hline Strain Code & 16S rRNA gene identification & GenBank accession No. \\
\hline DM 5 & Pseudomonas sp. & HQ400616 \\
EM 5 & Enterobacter aerogenes & HQ400617 \\
EM 9 & Exiguobacterium sp. & HQ400618 \\
OM 2 & Enterobacter aerogenes & HQ400619 \\
OM 3 & Enterobacter hormaechei & HQ400620 \\
OM 5 & Pantoea agglomerans & HQ400621 \\
OM 6 & Enterobacter aerogenes & HQ400622 \\
OM 8 & Enterobacter cloacae & HQ400623 \\
PM 9 & Enterobacter cloacae & HQ400624 \\
LC 1 & Enterobacter aerogenes & HQ400625 \\
\hline
\end{tabular}


quencing laboratory of Synergic scientific services, Chennai, India for sequencing. Ten partial 16S rDNA nucleotide sequences determined in this report have been deposited in the GenBank. (Table 2)

Amplicons obtained using the primers $\mathrm{pA}$ and $\mathrm{pH}$ have been used for the restriction analysis using HpaII, and $M s p$ I resstrictases. The restriction mixture contained $10 \mu \mathrm{L}$ of PCR product, 1.5 U of each of the restrictases and manufacturer's recommended buffer $(2.5 \mu \mathrm{L}$ of $10 \mathrm{x})$ up to $25 \mu \mathrm{L}$ volume. The reaction mixture was incubated at $37{ }^{\circ} \mathrm{C}$ for $2 \mathrm{~h}$ and the reaction was inactivated by heating at $70{ }^{\circ} \mathrm{C}$ for $10 \mathrm{~min}$. Restriction products were separated in 3\% agarose gel in TAE buffer. Medium size 100 bp DNA (GeNeI) ladder were used to estimate the size of the digested fragments.

Strains were genotypically characterized by BOXPCR, as described by Rademaker and De Bruijn (1997) using BOX A1R (5' - CTA CGG CAA GGC GAC GCT GAC G-3') as primer. Reaction was performed in $50 \mu \mathrm{L}$ reaction mixture containing: $5 \mu \mathrm{L}$ buffer $(10 \mathrm{x}), 1 \mu \mathrm{L}$ of BOX A1R, $1.5 \mu \mathrm{L}$ of each dNTP, $1 \mu \mathrm{L}$ of Taq DNA polymerase, $36.5 \mu \mathrm{L}$ of sterile bidistilled water and $4 \mu \mathrm{L}$ of template DNA. PCR-amplifications were performed in a GeneAmp ${ }^{\circledR}$ PCR system 9700 (Applied Biosystems, USA) and the temperature profile was as follows: initial denaturation at $95{ }^{\circ} \mathrm{C}$ for $6 \mathrm{~min}, 35$ cycles at $94{ }^{\circ} \mathrm{C}$ for $1 \mathrm{~min}$, annealing at $53^{\circ} \mathrm{C}$ for $1 \mathrm{~min}$, and extension at $65^{\circ} \mathrm{C}$ for $8 \mathrm{~min}$ followed by final extension at $65^{\circ} \mathrm{C}$ for $16 \mathrm{~min}$. Amplified products were separated by horizontal electrophoresis on $1.5 \%$ agarose gels.

\section{Field experiments}

Tomato and chili seeds were treated with bacterial suspensions of OM5 and EM9 strains $\left(10^{8} \mathrm{cfu} / \mathrm{mL}\right)$ as well as their combination (OM5+EM9 in equal parts) for $30 \mathrm{~min}$ and were shade dried at $28^{\circ} \mathrm{C}$ for $1 \mathrm{~h}$, the control seeds were coated with sterilized tap water. The treated seeds were sown in pots $(15-20 \mathrm{~cm})$ sterilized with $0.7 \%$ sodium hypochlorite solution, filled with red sand, soil and farmyard manure $(2: 1: 1)$ which was sterilized at $121{ }^{\circ} \mathrm{C}$ for $30 \mathrm{~min}$. Observations were recorded on germination percentage in the beginning, after one month of sowing, 10 seedlings from each replication were assessed for their root length, shoot length, wet weight and dry weight. Each treatment consisted of four replicates of 100 seeds each ( 25 seeds/pot) and the experiment was repeated three times.

\section{Data analysis and dendrogram}

For the analysis of ARDRA and BOX PCR molecular weight and Rf values of each band was determined by using 'Molecular Analyst software' (Version 1.5). The character state ' 1 ' was given for a band, which could be clearly and reproducibility detected in the gel and ' 0 ' was assigned if it was not possible to determine. The similarity coefficient and cluster analysis was performed (Janda, 1991) by the unweighted-pair-group method with arithmetic average
(UPGMA) of NTSYS-pc 2.02e (Applied Biosciences, Inc., New York, USA).

\section{Results}

\section{Morphological and Biochemical characteristics}

The characterized mud volcano and lime cave isolates (a total of 52 bacterial isolates) showed diverse morphological and cultural characteristics as indicated from variations in colony size and shape. On the basis of their Gram reaction, $10(19.2 \%)$ of the isolates were found to be Gram positive and about $42(80.8 \%)$ were Gram negative bacteria (Data not shown).

Upon subjecting to various biochemical tests, it was observed that 34 isolates $(65.4 \%)$ were able to degrade tryptophan to indole and pyruvic acid while other isolates showed negative reaction to indole test. Nearly $48.1 \%$ (25 isolates) of 52 isolates showed positive result for methyl red test, 27 isolates were shown to produce variable results and negative result for methyl red test. Twenty five isolates showed positive result to Voges Prauskauer test and nearly $51.9 \%$ isolates (27 isolates) showed variable and negative result to this test. Twenty three isolates utilized citrate and all the other isolates showed negative result for citrate utilization test. Only $30.8 \%$ isolates (16 isolates) were able to reduce nitrate to nitrite, while the rest of the isolates are non-reducers of nitrate. Starch hydrolysis results showed that 26 isolates $(50 \%)$ were able to hydrolysis starch as a source of carbon and remaining isolates did not hydrolyze the starch. (Data not shown)

\section{Plant growth promoting traits}

Based on morphological and biochemical variations 24 distinct isolates were screened for their PGPR potential. Of the 24 isolates 15 were able to produce IAA. The outer part of the mud volcano sample had the more number of IAA producers in relation to other sites. Only 15 out of the 24 isolates were able to solubilize phosphate. The mud volcano sample collected from the outer part showed the highest number of phosphate solubilizer strains in relation to the other sites. Only 7 isolates of 24 were able to produce siderophores. The outer part of the mud volcano sample presented the highest number of isolates that produce siderophores. Of the 24 isolates 5 were able to produce HCN. Dried part of the mud volcano sample had the highest number of hydrogen cyanide production than other sites. Out of 24, 10 isolate showed protease and cellulose production (Table 3).

Isolates OM5, DM5, DM6, EM9, LC6 showed positive result for more than four properties tested. There was no significant contribution of the area from where the samples collected, as demonstrated in Table 3. 
Table 3 - Bacterial isolates representing the plant growth promoting properties from mud volcano $\&$ lime cave.

\begin{tabular}{|c|c|c|c|c|c|c|}
\hline Isolate & IAA & Phosphatase & $\mathrm{HCN}$ & Sediropore & Protease & Cellulase \\
\hline PM 9 & + & - & - & - & - & - \\
\hline OM 2 & + & + & - & - & - & - \\
\hline OM 3 & + & + & - & - & - & - \\
\hline OM 4 & + & - & - & - & - & - \\
\hline OM 5 & - & + & + & + & + & - \\
\hline OM 6 & + & - & - & - & - & - \\
\hline OM 7 & + & + & - & - & - & - \\
\hline OM 8 & - & - & - & + & + & - \\
\hline OM 10 & - & - & - & - & - & + \\
\hline OM 11 & - & - & - & + & + & + \\
\hline DM 5 & + & + & + & + & + & + \\
\hline DM 6 & - & + & + & + & + & + \\
\hline DM 7 & + & + & - & - & - & + \\
\hline DM 8 & + & - & - & - & - & + \\
\hline DM 10 & + & - & - & - & - & - \\
\hline EM 4 & - & - & - & - & - & - \\
\hline EM 5 & + & - & - & - & - & + \\
\hline EM 6 & + & - & - & - & + & + \\
\hline EM9 & + & + & + & + & + & - \\
\hline EM 11 & - & - & - & - & + & + \\
\hline LC 1 & + & + & - & - & - & - \\
\hline LC 4 & - & + & - & - & - & - \\
\hline LC 5 & + & - & - & - & + & + \\
\hline LC6 & + & + & + & + & + & - \\
\hline
\end{tabular}

\section{Intrinsic antibiotic resistance and salt tolerance}

When susceptibility to antibiotics was investigated, isolates LC5, EM10 and EM3 showed sensitive to all antibiotics tested, none of the isolates showed resistant to all antibiotics. All OM isolates showed resistant to Ampicillin, Vancomycin and Amoxicillin. Whereas, DM isolates were resistant to Amoxycillin and Vancomycin and PM isolates showed resistant to Vancomycin. Isolates OM5 and EM4 tolerated high salt concentration of $12 \%$ (Data not shown).

\section{Biocontrol activity of the strains}

Isolates OM5, EM9 and LC6 showed antagonistic effects against mycelial growth of root rot fungus $S$. rolfsii (Inhibition zone greater that 40\%). Isolates LC6 (67.2\%) and EM9 (65.38\%) are the only two bacterial isolate which inhibited $P$. aphanidermatum significantly over the control. Mycelial growth of $R$. solani was inhibited by strains DM5 (65\%), EM9 (60\%) and LC6 (57.2\%). The antagonistic effect appeared after 3 days of incubation. Among 24 isolates EM9, OM8, OM5, OM11 and DM5 showed statistically significant highest mycelial inhibition of charcoal rot caus-
Table 4 - Bacterial isolates representing the antagonistic activity against four plant pathogens.

\begin{tabular}{|c|c|c|c|c|}
\hline $\begin{array}{l}\text { Isolate } \\
\text { name }\end{array}$ & $\begin{array}{l}\text { Macropho } \\
\text { mina sp. }\end{array}$ & $\begin{array}{c}\text { Pythium } \\
\text { aphanidermatum }\end{array}$ & $\begin{array}{l}\text { Sclerotium } \\
\text { rolfsii }\end{array}$ & $\begin{array}{c}\text { Rhizoctonia } \\
\text { solani }\end{array}$ \\
\hline PM 1 & 5 & 29.2 & 11.7 & 24.2 \\
\hline OM 2 & 29.2 & 29.2 & 37.5 & 20.2 \\
\hline OM 3 & 26.7 & 32.7 & 33.3 & 35 \\
\hline OM 4 & 28.3 & 24.2 & 37.5 & 33.3 \\
\hline OM 5 & 55.8 & 48.3 & 41.7 & 55.8 \\
\hline OM 6 & 36.7 & 41.7 & 40 & 25.8 \\
\hline OM 7 & 30 & 41.7 & 38.3 & 23.3 \\
\hline OM 8 & 57.5 & 46.7 & 20.8 & 36.7 \\
\hline OM 10 & 21.7 & 25 & 30 & 8.3 \\
\hline OM 11 & 51.7 & 44.2 & 5.8 & 35.8 \\
\hline DM 5 & 50 & 61.7 & 35 & 65 \\
\hline DM 6 & 29.2 & 29.2 & 22.5 & 38.3 \\
\hline DM 7 & 38.3 & 34.2 & 23.3 & 38.3 \\
\hline DM 8 & 40.8 & 33.3 & 30.8 & 33.3 \\
\hline DM 10 & 30.6 & 33.3 & 43.3 & 32.5 \\
\hline EM 4 & 16.7 & 0 & 3.3 & 1.7 \\
\hline EM 5 & 5 & 1.7 & 3.3 & 1.7 \\
\hline EM 6 & 5 & 1.7 & 1.7 & 6.7 \\
\hline EM 9 & 60 & 65.38 & 40.2 & 60 \\
\hline EM 11 & 3.3 & 1.7 & 3.3 & 8.3 \\
\hline LC 1 & 28.3 & 26.7 & 22.5 & 35 \\
\hline LC 4 & 11.7 & 25.8 & 35 & 38.3 \\
\hline LC 5 & 3.3 & 3.3 & 3.3 & 3.3 \\
\hline LC 6 & 52.5 & 67.2 & 40 & 57.2 \\
\hline
\end{tabular}

ing fungus Macrophomina sp. (Inhibition zone greater that $50 \%$ ) (Table 4).

\section{Molecular identification based on 16S rDNA sequence}

Undigested PCR products amplified with $\mathrm{pA}$ and $\mathrm{pH}$ primers produced a single band of about $1500 \mathrm{bp}$. ARDRA analysis revealed large variations among the isolates. Restriction pattern obtained after digestion of the amplified fragment with HpaII and MspI revealed 12 and 15 patterns respectively (Fig. 1a, b, c \& d).

Similarity analysis was then performed based on composite ARDRA profile, showed low similarity index around 58\% (Figure 2). Amplified patterns were observed in the band profiles obtained during genetic analysis. Consequently, we suppose that the PGPR and antagonistic effects would not be associated to a single genotype of wide distribution, but to a pronounced bacterial genetic diversity. Four groups were formed in the composite dendrogram analysis. Group I consists of isolates from dried and end point mud volcano, group II formed with four isolates each from end point and dried mud volcano and two iso- 

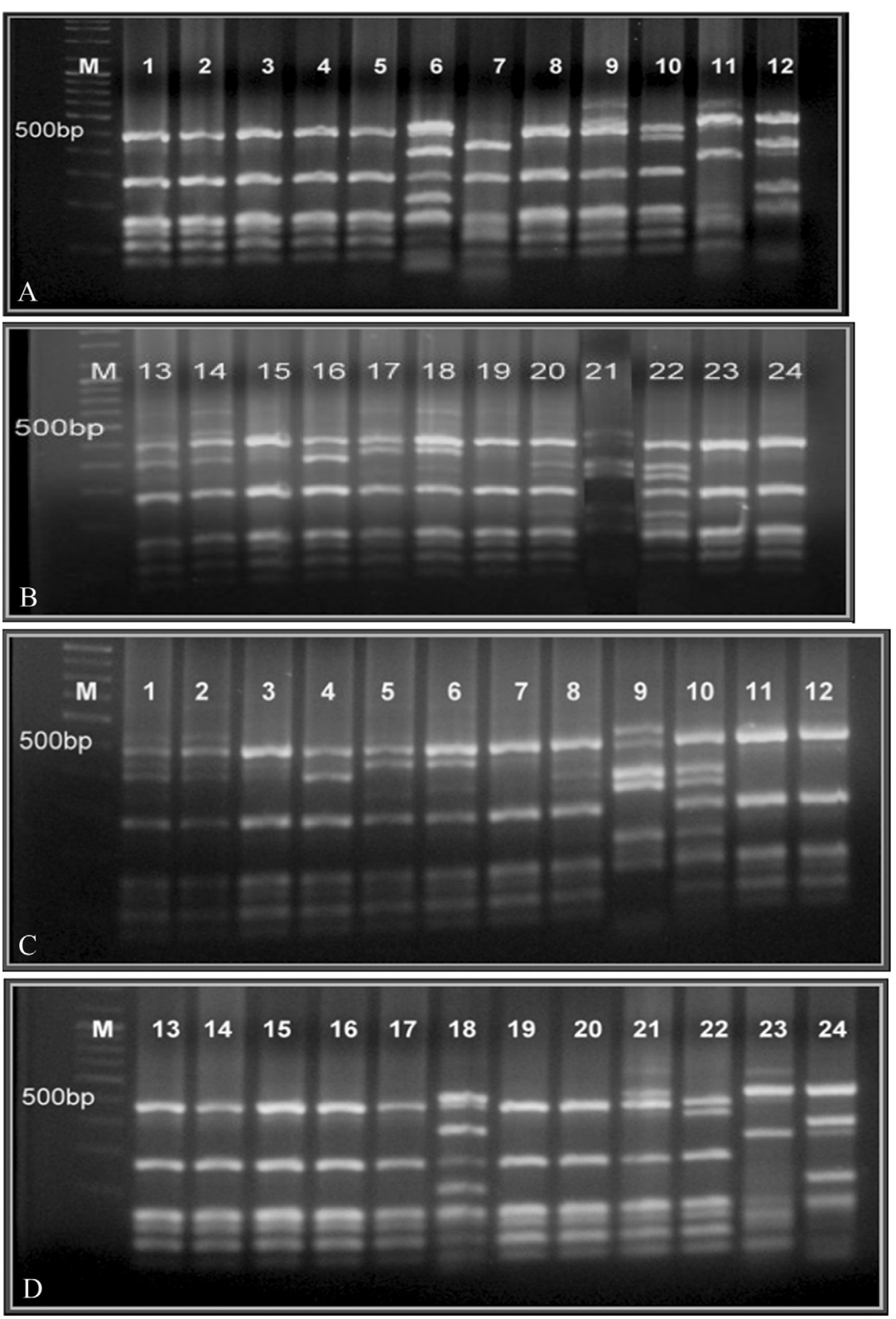

Figure 1 - Restriction Digestion pattern using enzyme MspI. Lane 1-24 (DM5-8, 10, EM4-6, 9, 11, OM2-8, 10, 11, PM9, LC1, 4-6). c\&d Restriction Digestion pattern using enzyme HpaII. Lane 1-24 (DM5-8, 10, EM4-6, 9, 11, OM2-8, 10, 11, PM9, LC1, 4-6).

lates from outside mud volcano. Group III comprised of predominantly outside mud volcano isolates followed by 2 isolates from lime cave and one isolate from point mud volcano. Group IV formed with two isolates of lime cave only. There is no grouping of correlation was observed among the isolates based on their respective antagonism and PGP properties.

\section{Genomic fingerprinting by BOX-PCR}

BOX sequences are regulatory sequences which can increase and decrease the specific gene expression (Lupski and Weinstock, 1992). Amplicons obtained by BOX-PCR were analysed on $3 \%$ agarose gel (Figure $3 \mathrm{a}, \mathrm{b}$ ).
Strains were grouped into four clusters with low similarity index (Figure 4). All the strains showed wide variations in fingerprinting pattern due to their high degree of genetic variability and distributed into different clusters.

\section{Field experiment}

Green house experiment analysis showed that there was an average increase of 14.2 and $27.4 \%$ in seedling emergence of chili and tomato respectively. Seed bacterization of chili and tomato have increased the secondary root numbers up to 56.8 and $46.5 \%$ respectively, significant increase in primary root length of both the plants were also noticed. Stem length of chili and tomato were also increased up to 10.5 and $38.1 \%$. No significant difference 


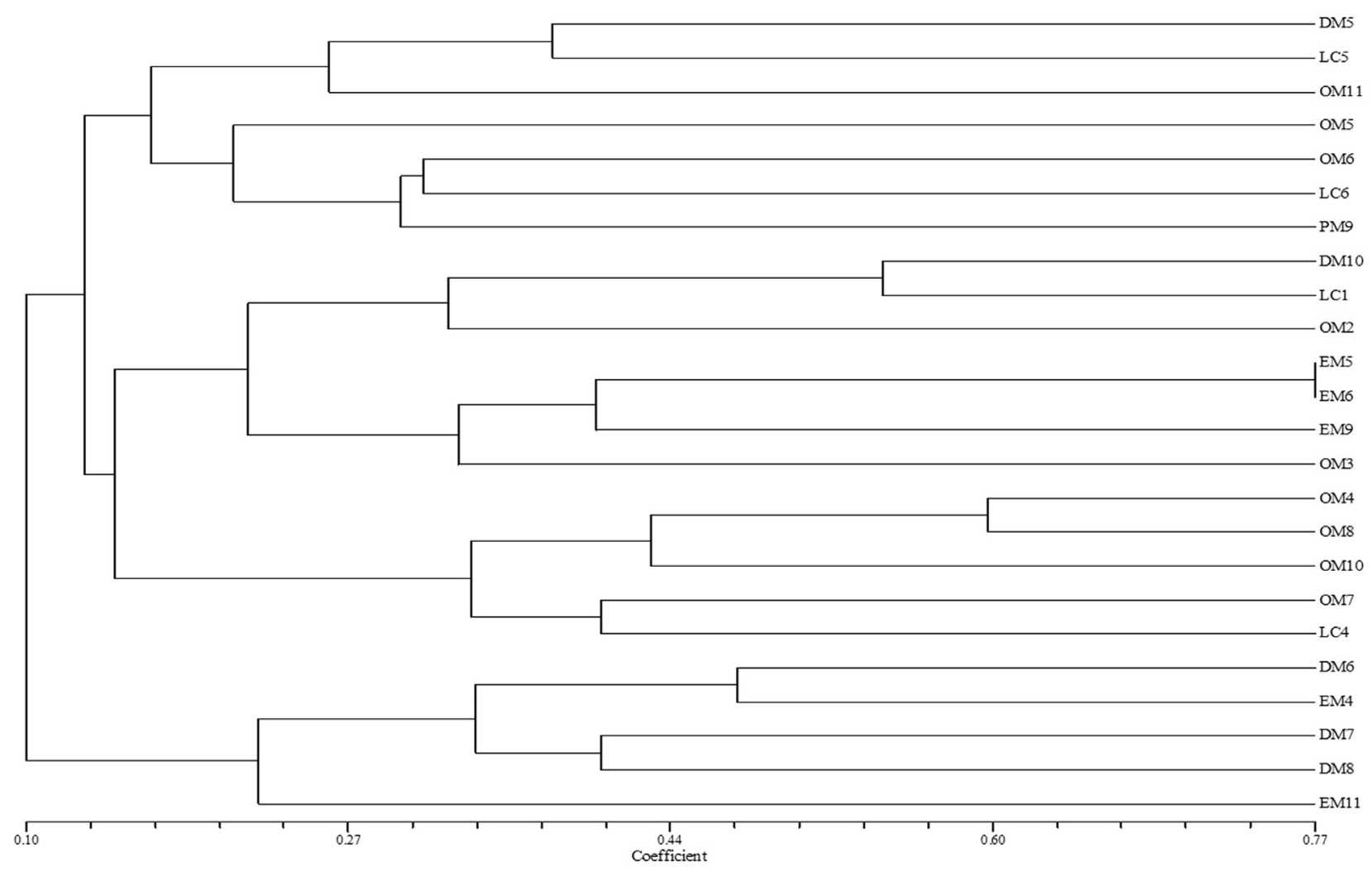

Figure 2 - Dendrogram showing the similarity co-efficient of Mud volcano \& Lime cave isolates based on ARDRA analysis using HpaII and MspI Restriction Enzymes.
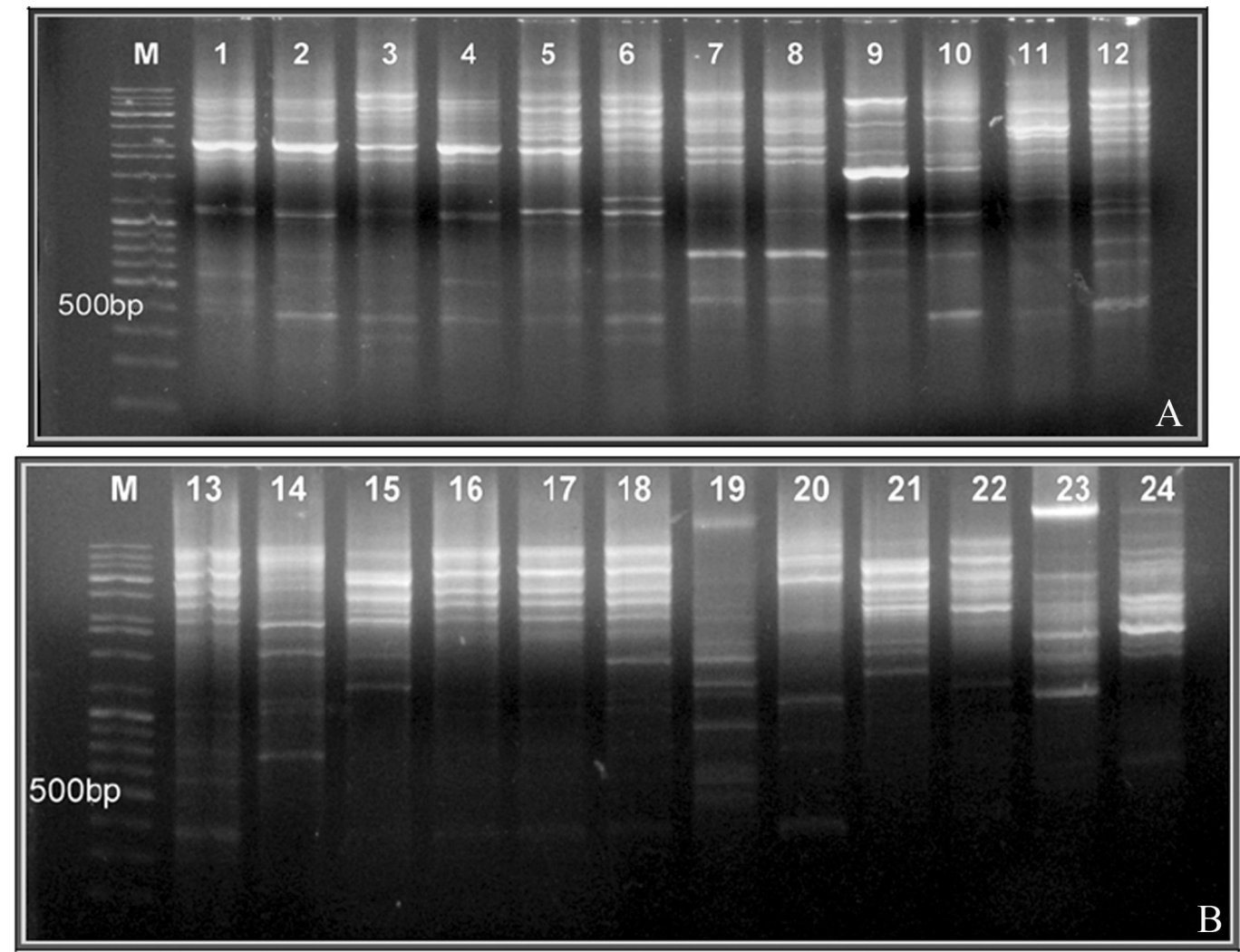

Figure 3 - Amplified patterns obtained by BOX-PCR Lane 1-24 (DM5-8, 10, EM4-6, 9, 11, OM2-8, 10, 11, PM9, LC1, 4-6). 


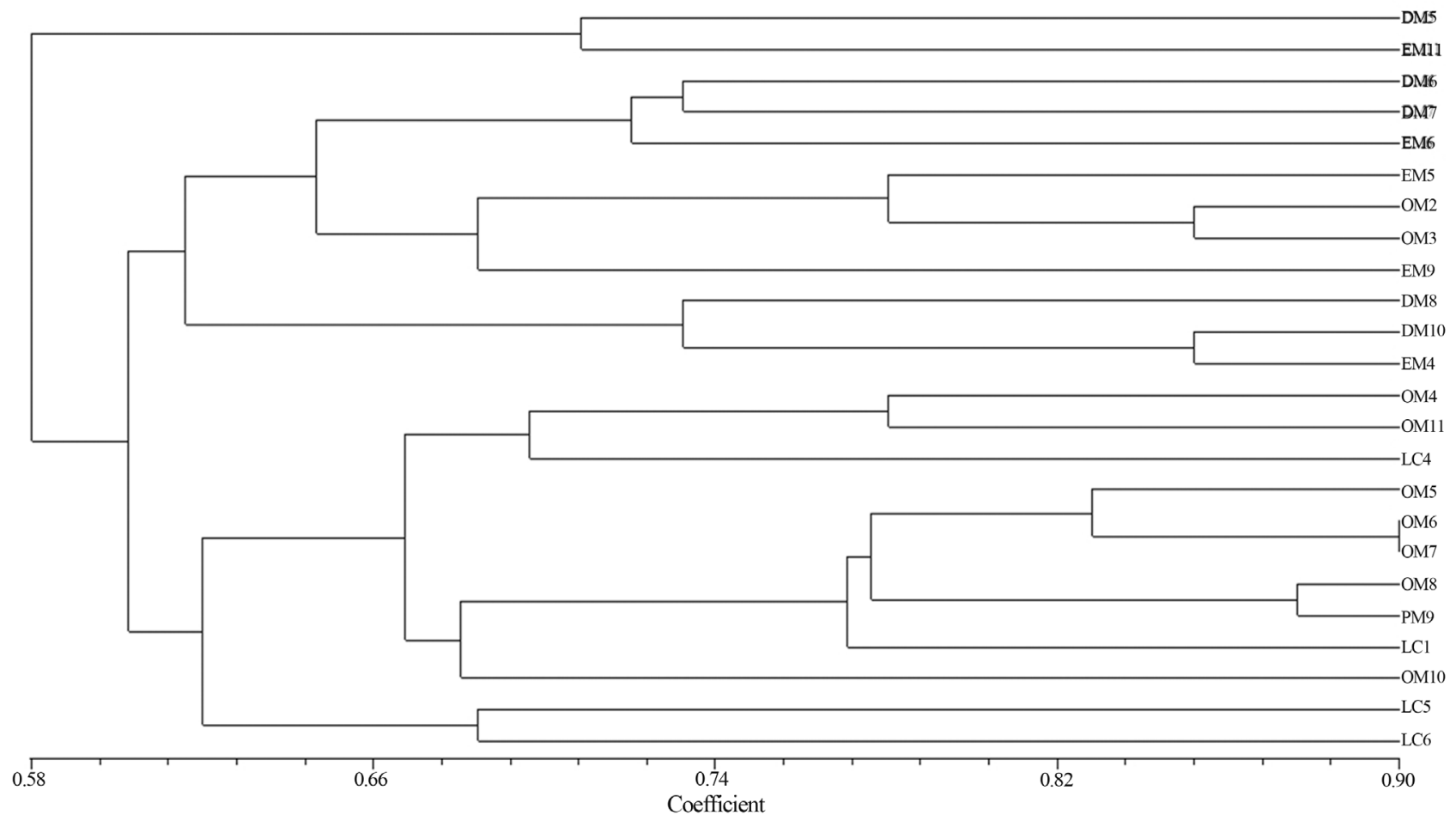

Figure 4 - Dendrogram showing the similarity co-efficient of Mud volcano and Lime cave isolates based on BOX-PCR analysis.

were noticed in fresh weight and dry weight of tomato plant but it was interesting to note that fresh and dry weight of chili plant was increased up to 91.2 and $135 \%$ respectively. Among all the different treatments, consortium of OM5 and EM9 showed best results in all parameters except fresh and dry weight of tomato (Table 5 and Figure 5).

\section{Discussion}

Present study is first to report the plant growth beneficial microorganisms in the active mud volcano and lime cave soil. As reported by several authors (Gilbert et al., 1993) that Gram negative ones are the most abundant rhizobacteria, around $80 \%$ of our isolates were Gram negative. Twenty four isolates were screened based on morphological and biochemical features. These isolates were screened for their potential PGPR characteristic. These twenty four isolates do not represent the bacterial diversity of the soil.

Plant auxin IAA produced by the bacteria enhances plant cell elongation or cell division thus stimulates better root growth (Glick et al., 1998). It was interesting to note that about $66 \%$ of our isolates are IAA producers. Under field conditions precipitated phosphates should be solubilized to readily available ones for plant growth, which can be done by plant growth promoting bacteria (Verma, 2001). Siderophore produced by bacteria binds to the free iron in the rhizosphere, thus favors the biocontrol agent than those of the pathogen (Siddiqui, 2005). Of the 24 isolates 7 were able to produce siderophores. Siderophores produced by the isolates should be studied for their affinity towards different iron complexes. Isolate DM5 showed positive response to all properties tested. Isolate EM9 showed positive response to all the above properties tested except cellulase production, isolate OM5 showed positive response to all the above properties tested except IAA and cellulase production. The above tested properties have been reported among the mechanisms by which the microorganisms promote plat growth (Niranjan et al., 2005), supporting the further evaluation of our isolates for their potentiality. One of the mechanisms of fungal inhibition is degrading their cell wall by lytic enzymes, hence the isolates were also screened for their protease and cellulase production. Ten isolates of 24 showed positive result for both the enzymes production. Growth and yield of several crop plants has been adversely affected by salinity, interaction of plant growth promoting bacteria helps the survival in adverse conditions. All 24 isolates showed positive result of which OM5 and EM4 showed highest tolerant rate.

Wide variety of bacterial species can be used to protect plants against fungal and bacterial diseases (Ren et $a l$., 2006). Our isolates were tested against phytopathogenic fungi Rhizoctonia solani, Pythium aphanidermatum, Macrophomina sp. and Sclerotium (Athelia) rolfsii to assess whether they can act as effective biocontrol agent. Isolates OM5 and EM9 showed comparatively effective antagonism against all pathogens tested and can be considered for good candidature as biocontrol agent. Observations indicated that bacteria use to compete with pathogens 

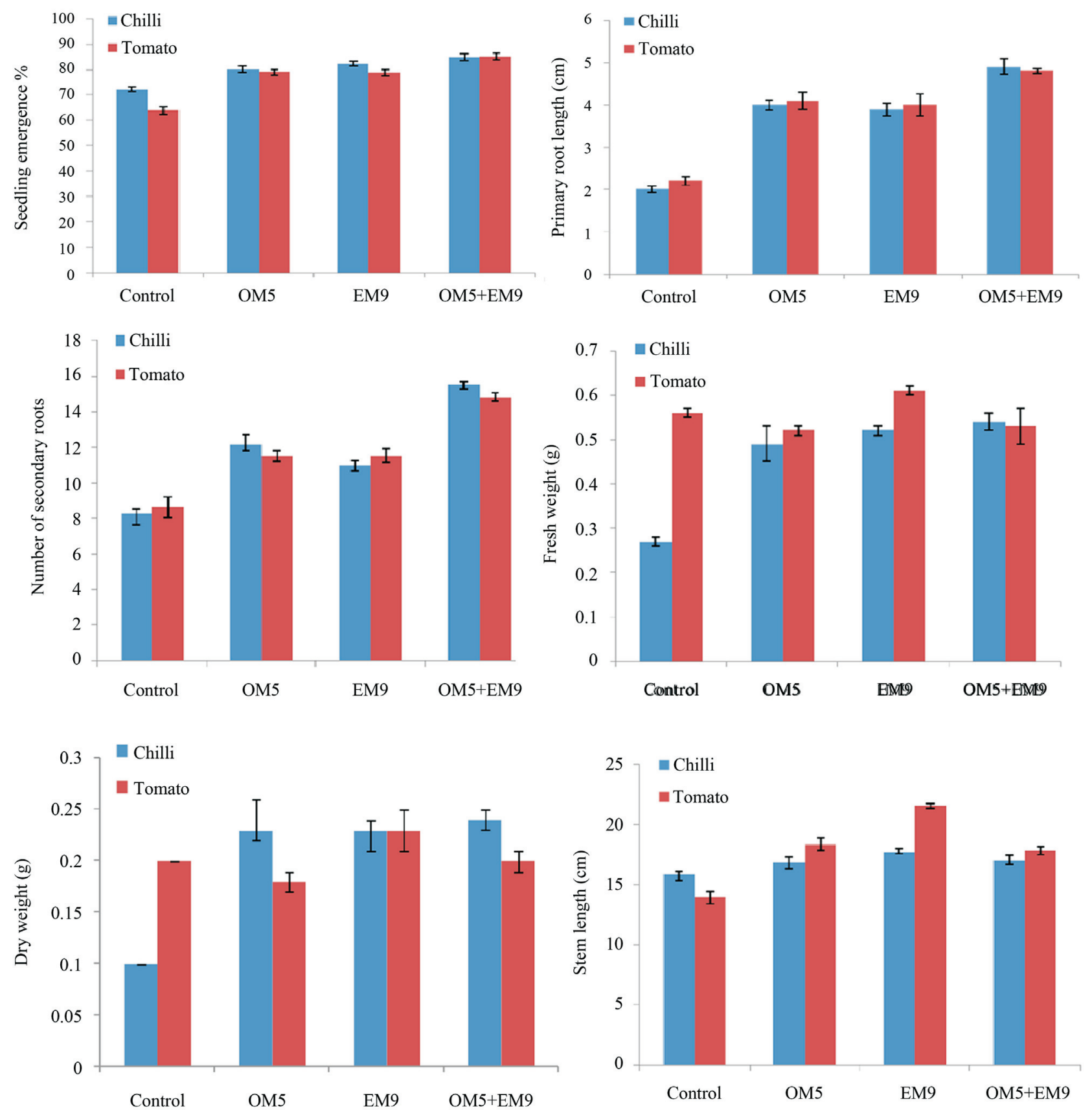

Figure 5 - Effect of seed bacterization of PGPR OM5 and EM9 (a) Seedling emergence, (b) Primary root length, (c) Number of secondary roots, (d) Fresh weight, (e) Dry weight and (f) Stem length. Seeds without any treatment (control), seeds co-inoculated with OM5 at cell concentration of $10^{8}$ cell/mL (OM5), seeds co-inoculated with EM9 (EM9) and seeds co-inoculated with consortium of OM5 and EM9 (OM5+EM9).

for the nutrients available in the culture media and also some diffusible compound secreted by the bacterial strains should be responsible for fungal inhibiton. Eventhough Pantoea agglomerans is considered as bacterial pathogen for rice, studies proved the ability of these strains to reduce incidence of fire blight in apple, pears and flowers (Elmer $e t$ al., 2005). It was also proved as most promising biocontrol agents for variety of bacterial and fungal diseases in plants (Rezzonico et al., 2009).
A similarity analysis was then performed based on composite ARDRA profile from the use of the two restriction endonucleases ( $H p a \mathrm{II}$ and $\mathrm{Msp} \mathrm{I}$ ) showed low similarity index around $58 \%$. In the genomic finger prints of potential isolates showed no particular correlation between the origin of the isolates and the ARDRA groups could be established. In BOX-PCR four groups were formed. There was a broad range of variations in their fingerprinting pattern due to their high degree of genetic variability and distributed into different clusters. On observation of these 
results, current study identified a high degree of genetic variability among different species as well as same species.

\section{Conclusion}

In last few decades there is increased need to explore varied ecological niches to find out beneficial microorganisms. Increasing awareness about the chemically synthesized fertilizers based agriculture practices, this study identified two isolates selected and genetically characterized (Pantoea agglomerans [OM5], Exiguobacterium sp. [EM9]) showed excellent antagonistic property as well as other plant growth promoting properties. Field trail experiments showed increase in the plant growth of tomato and chili by seed bacterization. Hence these isolates can be of good candidate for potential agricultural use as multipurpose organism, effective biocontrol agent and plant growth promoters.

\section{References}

Alain K, Holler T, Musat F, Elvert M, Treude T Krüger M (2006) Microbiological investigation of methane- and hydrocarbon-discharging mud volcanoes in the Carpathian Mountains, Romania. Environ Microbiol 8:574-90.

Anon (1957) Mannual of microbiological methods. Mc-Graw Hill Book Co., New York. p127.

Bakker AW, Schippers M (1957) Microbial cyanide production in the rhizosphere in relation to potato yield reduction and Pseudomonas spp. mediated plant growth-stimulation. Soil Bio Biochem 19:451-457.

Bauer AW, Kirby WM, Sherris JC, Turck M (1966) Antibiotic susceptibility testing by a standardized single disk method. American J Clin Pathol 45:493-496.

Bent E, Tuzun S, Chanway CP, Eneback S (2001) Alterations in plant growth and in root hormone levels of lodgepole pines inoculated with rhizobacteria. Can J Microbiol 47:793-800.

Chen W, Kuo T (1993) A simple and rapid method for the preparation of Gram negative bacterial genomic DNA. Nucleic Acids Res 21:2260.

Compant S, Duffy B, Nowak J, Clement C, Barka EA (2005) Use of plant growth-promoting bacteria for biocontrol of plant diseases: principles, mechanisms of action, and future prospects. Appl Environ Microbiol 71:4951-4959.

Dennis C, Webster J (1971) Antagonistic properties of species groups of Trichoderma. III. Hyphal interaction. Trans Brit Mycol Soc 57:363-369.

Edwards U, Rogall T, Blocker H, Emde M, Bottger EC (1989) Isolation and direct complete nucleotide determination of entire genes. Characterization of a gene coding for $16 \mathrm{~S}$ ribosomal RNA. Nucleic Acids Res 17:7843-7853.

Elmer PAG, Hoyte SM, Vanneste JL, Reglinski T, Wood PN, Parry FJ (2005) Biological control of fruit pathogens. N Z Plant Prot 58:47-54.

Freitas JR, Banerjee MR, Germida JJ (1997) Phosphate- solubilizing rhizobacteria enhance the growth and yield but not phosphorus uptake of canola (Brassica napus L). Biol Fert Soils 24:358-364.

García de Salamone IE, Do bereiner J, Urquiaga S, Boddey RM (1996) Biological nitrogen fixation in Azospirillum strain in 
maize genotype associations as evaluated by $15 \mathrm{~N}$ isotope dilution technique. Biol Fert Soils 23:249-256.

Gilbert GS, Parke JL, Clayton MK, Handelsman J (1993) Effects of an introduced bacterium on bacterial communities on roots. Ecol 74:840-854.

Glick BR, Penrose DM, Li J (1998) A model for the lowering of plant ethylene concentrations by plant growth promoting bacteria. J Theor Biol 190:63-68.

Jacob P (1996) Soil chemical analysis of activity areas in the archaeological site of piedras negras, Guatemala. Ph.D thesis, Brigham Young University, United States.

Janda JM (1991) Recent advances in the study of the taxonomy, pathogenicity, and infectious syndromes associated with the genus Aeromonas. Clin Microbiol Rev 4:397-410.

Lupski JR, Weinstock GM (1992) Short, interspersed repetitive DNA sequences in prokaryotic genomes. J Bacteriol 174:4525-4529.

Niranjan raj S, Shetty HS, Reddy MS (2005) Plant growthpromoting rhizobacteria: potential green alternative for plant productivity. In: Siddiqui ZA (ed) PGPR: Biocontrol and Biofertilization. Springer, Dordrecht, pp 197-216.

Pikovskaya RI (1948) Mobilization of phosphorus in soil in connection with vital activities by some microbial species. Microbiologia 17:362-370.

Rademaker JLW, De Bruijn FJ (1997) Characterization and classification of microbes by rep-PCR genomic fingerprinting and computer-assisted pattern analysis. In Caetano-Anolles G, Gresshoff PM (eds) DNA Markers: Protocols, Application and Overviews. John Wiley \& Sons, New York, pp 151-171.

Ren H, Gu G, Long J, Yin Q, Song T, Zhang S, Dong H (2006) Combinative effect of bacterial type-III effectors and a biocontrol bacterium on rice growth and disease resistance. J Biosci 3:617-627.
Reyes I, Bernier L, Antoun H (2002) Rock phosphate solubilization and colonization of maize rhizosphere by wild and genetically modified strains of Penicillium rugulosum. Micro Ecol 44:39-48.

Rezzonico F, Smits T, Montesinos E, Frey J, Duffy B (2009) Genotypic comparison of Pantoea agglomerans plant and clinical strains. BMC Microbiol 9:204.

Sarwar M, Kremer RJ (1992) Determination of bacterially derived auxins using a microplate method. Lett Appl Microbiol 20:282-285

Schwyn B, Neilands JB (1987) Universal chemical assay for the detection and determination of siderophores. Anal Biochem 160:47-56.

Siddiqui ZA (2005) PGPR: prospective biocontrol agents of plant pathogens. In: Siddiqui ZA (ed) PGPR: Biocontrol and Biofertilization. Springer, Dordrecht, pp 111-142.

Staffini F, Spezzaferri S, Aghib F (1993) Mud diapirs of the Mediterranean Ridge: Sedimentological and paleontological study of the mud breccia. Rivista Italiana di Paleontologia e Stratigsafia 99:225-254.

Sturz AV, Christie BR, Nowak J (2000) Bacterial endophytes: potential role in developing sustainable systems of crop production. Crit Rev Plant Sci 19:1-30.

Suslow TV, Schroth MN, Isaka M (1982) Application of a rapid method for Gram differentiation of plant pathogenic and saprophytic bacteria without staining. Phytopathol 72:917918.

Verma SC, Ladha JK, Tripathi AK (2001) Evaluation of plant growth promoting and colonization ability of endophytic diazotrophs from deep water rice. J Biotechnol 9:127-141.

Whipps JM (2001) Microbial interactions and biocontrol in the rhizosphere. J Exp Botany 52:487-511.

All the content of the journal, except where otherwise noted, is licensed under a Creative Commons License CC BY-NC. 